\title{
A comparison of new firm financing by gender: evidence from the Kauffman Firm Survey data
}

\author{
Susan Coleman · Alicia Robb
}

Accepted: 29 December 2008/Published online: 5 May 2009

(C) The Author(s) 2009. This article is published with open access at Springerlink.com

\begin{abstract}
This study uses data from the new Kauffman Firm Survey to explore gender differences in the use of start-up capital and subsequent financial injections by new firms. We find that, consistent with previous studies, women start their businesses with significantly lower levels of financial capital than men. A new finding from this research is that women go on to raise significantly lower amounts of incremental debt and equity in years two and three. These results hold even controlling for a variety of firm and owner characteristics, including the level of initial start-up capital and firm sales. Our findings also reveal that women rely heavily on personal rather than external sources of debt and equity for both start-up capital as well as follow-on investments. Our findings have implications for further research into gender differences in financing sources and strategies and business outcomes.
\end{abstract}

Keywords Gender differences · Financing sources $\cdot$ New firms $\cdot$ Start-up capital

S. Coleman

Barney School of Business, University of Hartford,

West Hartford, CT 06117, USA

e-mail: scoleman@hartford.edu

A. Robb $(\square)$

University of California at Santa Cruz, 59 Driftwood

Court, San Rafael, CA 94901, USA

e-mail: arobb@ucsc.edu
JEL Classifications J15 - L26 - M13-New Firms . Startups

\section{The importance of women-owned firms}

Small firms play a key role in the economic growth and vitality of the USA. The U.S. Small Business Administration (SBA) defines a small firm as one that has 500 or fewer employees. Using this definition, 99\% of all firms in the USA would be categorized as small businesses. Data compiled by the SBA indicate that there were 26.8 million small firms in this country in 2006 (Frequently Asked Questions 2008). These firms generated over half of the gross domestic product, employed half of all private sector employees, and were important creators of net new jobs. They are also a major source of innovation in the creation of new products, services, and technologies.

Women-owned firms represent a growing component of the small business sector. According to data from the U.S. Census Bureau, there were 6.5 million privately held women-owned firms in the USA in 2002 (2002 Survey of Business Owners). As shown in Table 1, these firms generated an estimated US $\$ 940$ billion in sales and employed 7.1 million people. Although women-owned firms still constitute a minority of all firms (28\%), their numbers have been growing rapidly. The number of women-owned firms increased by $19.8 \%$ from 1997 to 2002 compared with a growth rate of $10.3 \%$ for U.S. firms 
Table 1 U.S. non-farm firms by gender and ownership, 1997 and 2002

\begin{tabular}{|c|c|c|c|c|c|c|}
\hline \multirow[t]{2}{*}{ As published } & \multicolumn{2}{|l|}{ All firms } & \multicolumn{4}{|c|}{ Firms with paid employees } \\
\hline & $\begin{array}{l}\text { Firms } \\
\text { (number) }\end{array}$ & $\begin{array}{l}\text { Receipts (millions } \\
\text { of dollars) }\end{array}$ & $\begin{array}{l}\text { Firms } \\
\text { (number) }\end{array}$ & $\begin{array}{l}\text { Receipts (millions } \\
\text { of dollars) }\end{array}$ & $\begin{array}{l}\text { Employees } \\
\text { (number) }\end{array}$ & $\begin{array}{l}\text { Annual payroll } \\
\text { (millions of dollars) }\end{array}$ \\
\hline \multicolumn{7}{|l|}{ Women-owned firms } \\
\hline $2002^{\mathrm{a}}$ & $6,489,483$ & 940,775 & 916,768 & 804,097 & $7,146,229$ & 173,709 \\
\hline $1997^{\mathrm{b}}$ & $5,417,034$ & 818,669 & 846,780 & 717,764 & $7,076,081$ & 149,116 \\
\hline Growth $(\%)$ & 19.8 & 14.9 & 8.3 & 12.0 & 1.0 & 16.5 \\
\hline \multicolumn{7}{|l|}{ All U.S. firms } \\
\hline 2002 & $22,974,685$ & $22,627,167$ & $5,524,813$ & $21,859,758$ & $110,786,416$ & $3,813,488$ \\
\hline 1997 & $20,821,934$ & $18,553,243$ & $5,295,151$ & $17,907,940$ & $103,359,815$ & $2,936,493$ \\
\hline Growth $(\%)$ & 10.3 & 22.0 & 4.3 & 22.1 & 7.2 & 29.9 \\
\hline $\begin{array}{l}2002 \text { percentage of total } \\
\text { U.S. firms women-owned }\end{array}$ & 28.2 & 4.2 & 16.6 & 3.7 & 6.5 & 4.6 \\
\hline $\begin{array}{l}1997 \text { percentage of total } \\
\text { U.S. firms women-owned }\end{array}$ & 26.0 & 4.4 & 16.0 & 4.0 & 6.8 & 5.1 \\
\hline
\end{tabular}

2002 Survey of Business Owners, women-owned firms

b 1997 Survey of Women-Owned Business Enterprises

overall. The number of firms with employees increased by $8.3 \%$ for women-owned firms and just $4.3 \%$ for U.S. firms overall.

Yet during the same timeframe, the revenues for women-owned firms increased by less than $15 \%$, compared with $22 \%$ for U.S. firms overall (see Table 1 ). Employment by women-owned firms grew by only $1 \%$, compared with a growth rate of $7.2 \%$ for all U.S. firms. Finally, the payroll grew by $17 \%$, compared with $30 \%$ for U.S. firms overall. These Census Bureau statistics indicate that while the number of women-owned firms has grown faster than those owned by men, their relative importance in terms of sales, employment, and payroll has actually decreased over the same period. Women own less than $17 \%$ of firms with employees, employ less than $7 \%$ of the workforce, and account for just $5 \%$ of payroll. Women-owned businesses appear to have lost ground over the 1997-2002 period.

Women-owned firms have continued to struggle in a variety of areas. They tend to be significantly smaller than firms owned by men. In terms of performance, previous studies have revealed that women-owned firms are more likely to fail and have lower levels of sales, profits, and employment (Rosa et al. 1996; Robb 2002; Watson 2002). As shown in Table 1, women-owned firms generate less than $5 \%$ of all firm revenues and less than $4 \%$ of revenues from firms with employees. Women-owned firms also remain heavily concentrated in the service and retail sectors (Loscocco et al. 1991; Brush 1992; Du Rietz and Henrekson 2000; Fairlie and Robb 2008). Because these industries are highly competitive, opportunities for growth and profitability are limited. The Center for Women's Business Research reported that $69 \%$ of women-owned firms were in the service sector in 2006, while $14.4 \%$ were in retail trade (Key Facts About Women-Owned Businesses 2008).

Access to capital is a frequently cited problem for women business owners, and a recent study by Lee and Denslow (2004) noted that it is more of a problem during the early stages of a firm's development. Similarly, a study of nascent entrepreneurs conducted by Parker and Belghitar (2006) observed that those firm owners who actually succeed are much more likely to have both personal and external sources of capital to draw upon. In a study of over 1,000 Canadian firms, Orser et al. (2000) found that women were more concerned about access to capital than with any other business problem. Consistent with their difficulties in acquiring capital, a number of studies contend that women-owned firms tend to "underperform" relative to men-owned firms in measures of size, growth, and profits (Loscocco et al. 1991; Rosa et al. 1996; Robb 2002; Fairlie and Robb 2009).

In this paper, we compare firm, owner, and financing characteristics by gender using the newly 
available Kauffman Firm Survey (KFS) data. We compare and contrast the financing sources and experiences of women and men firm owners in order to identify financing gaps, specific financial challenges and constraints, and differences in financing strategy. To our knowledge, this is one of the first studies that will systematically describe, by gender, the firm characteristics and financing sources for a large sample of new firms.

\section{Characteristics of women-owned firms}

Prior research has documented distinct differences in the characteristics of women- and men-owned small firms (Brush 1992). A number of studies have noted that women-owned firms are smaller than men-owned firms in terms of sales, assets, and number of employees (Coleman 2002; Robb and Wolken 2002; Fairlie and Robb 2009). Also, as noted above, most women-owned firms are concentrated in the service and retail sectors (Kalleberg and Leicht 1991; Loscocco et al. 1991; Anna et al. 1999; Du Rietz and Henrekson 2000). Conversely, a very small percentage of women-owned firms are in rapid growth or high technology lines of business (Menzies et al. 2004; Morris et al. 2006).

Previous studies have also noted differences between women and men small business owners. Though well educated on average, women owners are less likely to have degrees in business or technical fields (Menzies et al. 2004). Similarly, they have fewer years of prior experience in industry or in managerial roles (Carter et al. 1997; Boden and Nucci 2000; Fairlie and Robb 2009). In this sense, they have lower levels of human capital than male business owners. The same holds true with levels of financial capital. Prior research suggests that women start their businesses with smaller amounts of capital and are less likely to raise capital from external sources (Robb and Wolken 2002; Constantinidis et al. 2006; Orser et al. 2006; Fairlie and Robb 2009).

Finally, prior research has revealed differences in the motivations and anticipated rewards of business ownership for women and men. Specifically, while men are more likely to be motivated by firm growth and profits, women seek personal fulfillment, flexibility, and a sense of having more control over their destinies (Anna et al. 1999; Carter et al. 2003a, b; Morris et al. 2006). Some researchers have suggested that the desire for control and a higher level of risk aversion lead women business owners to keep their firms small and manageable (Cliff 1998; Orser and Hogarth-Scott 2002; Morris et al. 2006). By the same token, women are more likely to avoid external sources of financing which would force them to give up control and take on higher levels of risk (Verheul and Thurik 2001; Constantinidis et al. 2006). Taken together, these various characteristics and motivations for women-owned firms may have an effect on the types of capital they seek and are able to obtain. That premise will be a focal point of this research.

\section{Women-owned firms and financing}

A number of studies have examined women business owners' use of different sources of financing. Prior research suggests that there are both supply side and demand side issues in the acquisition of financial capital. Supply side factors would include the preferences of investors for specific types of industries, firms, or entrepreneurs. Conversely, demand side issues would include the preferences of the entrepreneur for growth, profits, industry sector, risk, and control. In this research, we will address both demand and supply side considerations as we examine women entrepreneurs' use of debt and equity.

\subsection{Debt financing}

In the area of debt financing, women continue to report difficulty in securing bank loans and dealing with lenders. This is troubling given that most studies indicate that women are no more likely to be turned down for loans than men. Women were more reluctant to apply, however, and they were more likely to anticipate denial. There is also evidence that women apply for significantly smaller loans that may not be sufficient to fund the growth of their firms. This suggests that both supply and demand side factors are at work in terms of women's willingness to seek and ability to obtain debt capital.

One study of Canadian firms by Fabowale et al. (1995) noted that women were less satisfied with their banking relationships, although they were no less likely to be granted loans. Similarly, an article by Walker and Joyner (1999) observed that women continue to feel that they are discriminated against in 
their attempts to secure funding. Using data from the 1998 Survey of Business Finances (SSBF), Coleman (2002) observed that women were significantly more reluctant to apply for loans than men in spite of the fact that they were no more likely to be turned down if they did apply. Cole and Mehran (2009) found similar results using data from the 2003 SSBF. Although commercial banks are typically a major source of financing for small firms, only $27 \%$ of women-owned firms used them in 1998 (Coleman 2002). These findings were echoed in a subsequent study by Treichel and Scott (2006) using data from three surveys conducted by the National Federation of Independent Business. Treichel and Scott also found that women were less likely to apply for bank loans, although they were no less likely to be approved. A study by Robb and Wolken (2002) found that women were more likely to borrow through the use of credit cards, thus avoiding the necessity of dealing with banks or lending officers.

Recent studies of bank borrowing by small firms suggest that loan applications may be affected by structural factors, such as firm size and industry sector. In a study of Canadian firms, Orser et al. (2006) found no differences in the likelihood of seeking debt capital when they controlled for firm size and industry sector. Similarly, women were no less likely to be approved once they had applied for a loan. Constantinidis et al. (2006) found differences in both demand and supply side patterns when they studied women entrepreneurs in Belgium. Ironically, although $86 \%$ of their loan requests were approved, almost $50 \%$ of the women surveyed indicated that they experienced barriers in their attempts to secure loans. When they categorized the firms by growth potential, the authors found that women in high growth or traditionally male-dominated lines of business encountered fewer gender-related barriers to borrowing than women in more traditional service or retail lines of business. Constantinidis et al. (2006) found a high level of risk aversion in the women entrepreneurs they interviewed and concluded that women may choose lifestyle types of businesses to balance family and business demands and to avoid dependence on external sources of capital.

\subsection{Equity financing}

There is considerably less research on women entrepreneurs' use of equity capital. Although women rely heavily on internal sources of equity, only a small percentage of firms actually use external equity in the form of angel investments or venture capital. Chaganti et al. (1996) found that women tend to use internal rather than external sources of equity for their firms. They concluded that this use of internal sources hampers their ability to grow and to introduce new products and services. In a subsequent study of the financial structure of small firms, Haynes et al. (2000) found that women family business owners had lower levels of income and that their firms had lower levels of equity than men-owned firms. These findings were echoed in a study by Carter et al. (2003a, b) using a sample of over 200 women business owners. They found that only $17 \%$ of their sample had any type of equity investment. The authors found that having a graduate education in any field was a significant predictor for firms' ability to secure equity financing.

The authors of the Diana Project (Brush et al. 2001) found that between 1953 and 1998, less than $5 \%$ of total venture capital funding went to womenowned firms. They concluded that this low level of funding was at least partially due to the relatively small number of women employed in the venture capital industry. Becker-Blease and Sohl (2007) surveyed angel investor portals to find that only $9 \%$ of the proposals received were from women entrepreneurs compared with $91 \%$ from men. However, women were significantly more likely to apply for funding to angel networks that had a higher proportion of women angel investors. This suggests that the relatively small number of women who are capable of being investors may be a factor in women entrepreneurs' relative unwillingness to apply for external equity.

One consensus arising from the several studies examining women entrepreneurs' use of both debt and equity is that, whatever the source of capital, women do not raise enough of it. This fact hampers their ability to grow and increases the risk of financial distress if the firm does not have sufficient liquidity to weather periods of adversity. Amatucci and Sohl (2004) did a series of in-depth interviews with women entrepreneurs who used angel investments. In general, the women indicated that they wished that they had sought funding sooner and had raised more money. In a study of Norwegian firms, Alsos et al. (2006) found that women applied for significantly 
smaller amounts of capital than men. Thus, although they were just as likely to apply for and receive loans, they did not raise enough capital to fund the growth of their firms. In a study of U.S. firms, Treichel and Scott (2006) also found that women-owned firms applied for significantly smaller loans than men, even controlling for other factors.

Taken together, these studies point to continued difficulty on the part of women entrepreneurs in accessing both debt and equity sources of financial capital. Further, previous research suggests constraints and barriers in dealing with the providers of those sources of capital. This study will seek to delve into these issues more fully using data from the Kauffman Firm Survey.

\section{Data}

The Kauffman Firm Survey is a longitudinal survey of new businesses in the USA. This survey collected information on 4,928 firms that started in 2004 and surveys them annually. This cohort is the first large national sample of firm start-ups that will be tracked over time. These data contain detailed information on both the firm and up to ten business owners per firm. In addition to the 2004 baseline year data, there are 2 years of follow-up data (2005 and 2006) now available. Additional years are planned. Detailed information on the firm includes industry, physical location, employment, profits, intellectual property, and financial capital (equity and debt) used at start-up and over time. Information on up to ten owners includes age, gender, race, ethnicity, education, work experience, and previous start-up experience. The details provided by these data allow us to compare the financial strategies and the use of both debt and equity for new women- and men-owned firms over the period 2004 through 2006 . $^{1}$

A subset of the confidential dataset is used in this research - those firms that have data for all 3 survey

\footnotetext{
${ }^{1}$ For more information about the KFS survey design and methodology, see Ballou et al. (2008). A public use data set can be is available for download from the Kauffman Foundation's website, and a more detailed confidential dataset is available to researchers through a data enclave provided by the National Opinion Research Center (NORC). For more details about how to access these data, please see www.kauffman. org/kfs.
}

years and those that have been verified as going out of business in either 2005 or 2006 . This reduces the sample size to 4,163 businesses. The method for assigning owner demographics at the firm level was to define a primary owner. For firms with multiple owners (35\% of the sample), the primary owner was designated by the largest equity share. In cases where two or more owners owned equal shares, hours worked and a series of other variables were used to create a rank ordering of owners in order to define a primary owner. ${ }^{2}$ Firms with a primary owner that was female are classified as women-owned firms. Multirace/ethnic owners are classified into one race/ ethnicity category based on the following hierarchy: black, Asian, other, Hispanic, and white. For example, an owner is defined as black, even if he/she is also Hispanic. As a result of the ordering, the white category includes only non-Hispanic white.

Table 2 provides descriptive statistics, by primary owner gender, for various sources of equity and debt used at start-up in 2004, the baseline year. It reveals that roughly the same percentage of women and men used equity (80\%) and debt (55\%) for initial capital injections. Nevertheless, the specific sources differed by gender. Consistent with prior research, the vast majority of both women and men used internal rather than external equity to finance their firms. About $80 \%$ of women used internal equity while only $8.2 \%$ used external equity. Further, the major sources of external equity for women were funds provided by either a spouse or a parent. Only a very small percentage of women used outside equity investors $(1.5 \%)$ or venture capital financing $(0.2 \%)$. Although men were more likely to use external equity during the first year of operations than women (10.2 vs. $8.2 \%)$, the percentages were still very low.

Table 2 also reveals a higher percentage of women used personal rather than business debt to finance their firms (49.7 vs. 20.9\%). Major sources of funding were personal credit card balances $(32.7 \%)$, personal bank loans $(15.8 \%)$, business credit card balances in the owner's name (13.4\%), and family loans (10.7\%). Conversely, only $5.3 \%$ of women had bank loans for firm financing, and only $4.9 \%$ had a line of credit. Although the percentages of business debt were higher for men-owned firms (25.6 vs. $20.9 \%$ ), they

${ }^{2}$ For more information on this methodology, see Ballou et al. 2008. 
Table 2 New firm financing by primary owner gender according to the Kauffman Firm Survey (percentage of active firms)

\begin{tabular}{|c|c|c|c|c|c|c|}
\hline \multirow[t]{2}{*}{ Descriptive statistics } & \multicolumn{2}{|c|}{ Baseline 2004} & \multicolumn{2}{|c|}{ First follow-up 2005} & \multicolumn{2}{|c|}{ Second follow-up 2006} \\
\hline & Female $(\%)$ & Male (\%) & Female (\%) & Male (\%) & Female (\%) & Male $(\%)$ \\
\hline Total equity & 80.5 & 80.1 & 47.3 & 50.0 & 44.7 & 39.7 \\
\hline Total debt & 55.5 & 55.7 & 51.4 & 55.2 & 48.9 & 57.9 \\
\hline Inside equity [owner(s)] & 79.8 & 79.1 & 46.6 & 47.7 & 42.4 & 37.6 \\
\hline Outside equity & 8.2 & 10.2 & 4.5 & 6.9 & 5.6 & 5.3 \\
\hline Spouse equity & 2.1 & 1.5 & 1.1 & 1.2 & 0.9 & 1.1 \\
\hline Parent equity & 3.4 & 3.5 & 2.1 & 2.4 & 2.4 & 1.4 \\
\hline Other equity (individuals) & 1.5 & 3.2 & 1.1 & 2.1 & 1.5 & 1.6 \\
\hline Other equity (business) & 0.3 & 1.5 & 0.5 & 1.7 & 0.7 & 1.5 \\
\hline Venture capital equity & 0.2 & 0.6 & 0.2 & 0.6 & 0.0 & 0.5 \\
\hline Owner debt & 49.7 & 47.2 & 46.7 & 47.1 & 43.2 & 48.6 \\
\hline Personal credit card balances & 32.7 & 27.6 & 27.6 & 25.5 & 22.5 & 24.3 \\
\hline Bank loans & 15.8 & 17.5 & 9.5 & 10.5 & 9.9 & 11.6 \\
\hline Business credit card balances & 13.4 & 14.2 & 21.5 & 22.3 & 23.2 & 26.5 \\
\hline Family loan & 10.7 & 9.4 & 8.1 & 7.3 & 6.4 & 7.7 \\
\hline Other loan & 1.5 & 2.2 & 0.9 & 1.4 & 0.4 & 1.5 \\
\hline Other debt & 0.9 & 1.4 & 0.8 & 0.9 & 0.6 & 0.6 \\
\hline Total business debt & 20.9 & 25.6 & 23.4 & 29.4 & 22.5 & 32.1 \\
\hline Business credit card balances & 10.7 & 11.9 & 15.5 & 17.2 & 15.5 & 19.2 \\
\hline Bank loan & 5.3 & 6.6 & 3.9 & 6.6 & 3.8 & 6.8 \\
\hline Credit line & 4.9 & 5.4 & 5.1 & 8.5 & 6.6 & 11.1 \\
\hline Nonbank loan & 0.7 & 2.0 & 1.1 & 1.5 & 0.8 & 1.9 \\
\hline Family loan & 2.6 & 3.1 & 2.5 & 2.6 & 1.9 & 2.7 \\
\hline Owner loan & 1.4 & 1.5 & 1.5 & 1.1 & 0.5 & 0.7 \\
\hline
\end{tabular}

Source: Tabulations of the Kauffman Firm Survey confidential microdata

also reveal a minimal use of bank financing. This finding is consistent with prior research that attests to the difficulties faced by smaller and newer firms in their attempts to secure external sources of capital (Lee and Denslow 2004).

In addition to providing information on sources of debt and equity for the baseline year, Table 2 also provides similar data for the follow-on years of 2005 and 2006, which reveal similar patterns. Both women and men were more likely to use internal rather than external sources of equity; the outside investors or venture capital funding continued to be minimal. Similarly, both men and women continued to be more reliant on personal debt rather than business debt. Nevertheless, by 2006, almost twice as many men used bank loans for the business or lines of credit than women (17.9 vs. $10.4 \%)$. It is noteworthy that for 2004, 2005, and 2006, credit cards, either personal or business, were the major source of debt financing for both women and men.

Table 3 sheds further light on the amounts of debt and equity used by new firms. It reveals that women used dramatically lower amounts of total capital, debt, and equity to start their firms than men. Mean amounts of start-up capital in the baseline year (2004) were US\$54,375 for women compared with US $\$ 80,285$ for men. The differences are even more dramatic when we look at external sources of capital. Men used more than twice as much business debt to establish their firms as women (US\$21,885 vs. US\$9,312), while women were more reliant on owner or personal debt. Similarly, men used almost threefold more external equity as women (US\$11,224 vs. US\$3,196). The fact that women small business owners start their firms with much smaller amounts of capital may have implications for their ability to hire 
Table 3 New firm financing by primary owner gender according to the Kauffman Firm Survey

\begin{tabular}{|c|c|c|c|c|c|c|}
\hline \multirow[t]{2}{*}{ Debt/equity of new firms } & \multicolumn{2}{|c|}{ Baseline 2004} & \multicolumn{2}{|c|}{ First follow-up 2005} & \multicolumn{2}{|c|}{ Second follow-up 2006} \\
\hline & Female & Male & Female & Male & Female & Male \\
\hline Total financial capital invested (US\$) & 54,375 & 80,285 & 34,122 & 63,526 & 31,455 & 59,584 \\
\hline Total debt (US\$) & 30,510 & 41,488 & 22,216 & 39,151 & 22,174 & 41,379 \\
\hline Owner debt & 21,198 & 19,603 & 14,696 & 19,308 & 13,197 & 18,638 \\
\hline Business debt & 9,312 & 21,885 & 7,520 & 19,842 & 8,977 & 22,741 \\
\hline Equity investment (US\$) & 23,865 & 38,797 & 11,787 & 24,701 & 9,182 & 17,800 \\
\hline Internal equity & 21,704 & 29,920 & 8,641 & 15,446 & 7,451 & 12,180 \\
\hline External equity & 3,196 & 11,224 & 3,265 & 8,930 & 1,830 & 6,024 \\
\hline \multicolumn{7}{|l|}{ Leverage ratios $(\%)$} \\
\hline Debt/equity & 127.8 & 106.9 & 188.5 & 158.5 & 241.5 & 232.5 \\
\hline Debt/total FK & 56.1 & 51.7 & 65.1 & 61.6 & 70.5 & 69.4 \\
\hline Internal equity/total FK & 39.9 & 37.3 & 25.3 & 24.3 & 23.7 & 20.4 \\
\hline External equity/total FK & 5.9 & 14.0 & 9.6 & 14.1 & 5.8 & 10.1 \\
\hline
\end{tabular}

Source: Tabulations of the Kauffman Firm Survey confidential microdata

employees, develop new products and services, grow, or even survive.

As with the data in Table 2, a similar pattern persists in the follow-on years of 2005 and 2006. In both years, women raised roughly half of the amount of incremental financing that men did. The discrepancies are even more extreme when we consider the categories of business debt and external equity where the amount of new capital raised by women was closer to one-third of that raised by men. To summarize, for the first 3 years of operation, women-owned firms raised an average of approximately US $\$ 120,000$ compared to more than US\$200,000 for firms owned by men. Similarly, women raised a total of US $\$ 25,000$ of business debt and US\$8,000 of external equity, compared with US\$64,000 in business debt and US $\$ 26,000$ of external equity for men.

The data in Tables 2 and 3 suggest differences in the financing sources and strategies of women- and men-owned firms. Specifically, women start their firms with much smaller amounts of financial capital than men, and they are more likely to rely on internal rather than external sources of capital. Beyond those differences, only a small percentage of either women or men used external capital in the form of business loans, lines of credit, angel investments, or venture capital. These findings suggest the possibility of both supply and demand side constraints on new firms in general and on new women-owned firms in particular.
The fact that so few firms, male or female, use external sources of business debt or equity suggests constraints on supply, possibly driven by the high risk and potential for failure among newer firms. The fact that women-owned firms start their firms with dramatically less capital than men suggests constraints on demand. As suggested by prior research (Cliff 1998; Constantinidis et al. 2006), women may be more risk averse than men, or they may be more motivated to start smaller firms that will allow them to balance the demands of work and family (Brush 1992; Boden 1999). Alternatively, women may experience subtle forms of discrimination or difficulty in securing access to networks used by providers of external capital (Brush et al. 2002; Marlow and Patton 2005). Multivariate analysis was used as a next step to determine if the patterns revealed in Tables 2 and 3 persist after controlling for other variables that could affect access to capital.

\section{Multivariate analysis}

Further information on the likelihood of using new debt or new equity in the combined follow-on years of 2005-2006 is presented in Table 4. In this instance, probit analysis was used to determine the probability of a firm's use of new financial injections in 2005 and 2006. Column A presents total financial capital investments, while columns B and C show this 
Table 4 Multivariate analyses of new financial capital investments (2005 and 2006)

\begin{tabular}{|c|c|c|c|}
\hline \multirow[t]{2}{*}{ Coefficients } & \multicolumn{3}{|l|}{ DPROBITS } \\
\hline & $\begin{array}{l}\text { New FK } \\
\text { investments }\end{array}$ & $\begin{array}{l}\text { New equity } \\
\text { investments }\end{array}$ & $\begin{array}{l}\text { New debt } \\
\text { investments }\end{array}$ \\
\hline Black & $\begin{array}{l}-0.00685 \\
(0.0298)\end{array}$ & $\begin{array}{l}0.124 * * * \\
(0.0321)\end{array}$ & $\begin{array}{l}-0.0523 \\
(0.0342)\end{array}$ \\
\hline Asian & $\begin{array}{l}-0.0216 \\
(0.0427)\end{array}$ & $\begin{array}{l}-0.0207 \\
(0.0469)\end{array}$ & $\begin{array}{l}-0.0112 \\
(0.0486)\end{array}$ \\
\hline ther & $\begin{array}{l}0.0389 \\
(0.0509)\end{array}$ & $\begin{array}{l}0.119^{*} \\
(0.0609)\end{array}$ & $\begin{array}{l}-0.0295 \\
(0.0628)\end{array}$ \\
\hline Hispanic & $\begin{array}{l}0.0110 \\
(0.0356)\end{array}$ & $\begin{array}{l}0.0386 \\
(0.0407)\end{array}$ & $\begin{array}{l}0.0352 \\
(0.0403)\end{array}$ \\
\hline Female & $\begin{array}{l}-0.0491 * * \\
(0.0194)\end{array}$ & $\begin{array}{l}-0.0360^{*} \\
(0.0219)\end{array}$ & $\begin{array}{l}-0.0598^{* * *} \\
(0.0218)\end{array}$ \\
\hline Hours worked & $\begin{array}{l}0.00233 * * * \\
(0.000378)\end{array}$ & $\begin{array}{l}0.00117 * * * \\
(0.000417)\end{array}$ & $\begin{array}{l}0.00341 * * * \\
(0.000428)\end{array}$ \\
\hline Age & $\begin{array}{l}0.00739 \\
(0.00491)\end{array}$ & $\begin{array}{l}-0.00316 \\
(0.00572)\end{array}$ & $\begin{array}{l}0.00686 \\
(0.00571)\end{array}$ \\
\hline Age squared & $\begin{array}{l}-0.0000799 \\
(0.0000519)\end{array}$ & $\begin{array}{l}0.0000412 \\
(0.0000606)\end{array}$ & $\begin{array}{l}-0.0000881 \\
(0.0000605)\end{array}$ \\
\hline High school graduate & $\begin{array}{l}0.0734 \\
(0.0509)\end{array}$ & $\begin{array}{l}0.0215 \\
(0.0691)\end{array}$ & $\begin{array}{l}0.0751 \\
(0.0639)\end{array}$ \\
\hline Some college & $\begin{array}{l}0.0863^{*} \\
(0.0521)\end{array}$ & $\begin{array}{l}0.0417 \\
(0.0655)\end{array}$ & $\begin{array}{l}0.116^{*} \\
(0.0613)\end{array}$ \\
\hline College degree & $\begin{array}{l}0.0877^{*} \\
(0.0514)\end{array}$ & $\begin{array}{l}0.0338 \\
(0.0663)\end{array}$ & $\begin{array}{l}0.0828 \\
(0.0623)\end{array}$ \\
\hline Graduate degree & $\begin{array}{l}0.0937^{*} \\
(0.0494)\end{array}$ & $\begin{array}{l}0.0701 \\
(0.0672)\end{array}$ & $\begin{array}{l}0.113^{*} \\
(0.0616)\end{array}$ \\
\hline Work experience (years) & $\begin{array}{l}-0.00176^{* *} \\
(0.000828)\end{array}$ & $\begin{array}{l}-0.000363 \\
(0.000966)\end{array}$ & $\begin{array}{l}-0.00233 \text { ** } \\
(0.000953)\end{array}$ \\
\hline Start-up experience & $\begin{array}{l}0.0306^{*} \\
(0.0168)\end{array}$ & $\begin{array}{l}0.0523 * * * \\
(0.0193)\end{array}$ & $\begin{array}{l}0.0175 \\
(0.0192)\end{array}$ \\
\hline Team ownership & $\begin{array}{l}-0.00627 \\
(0.0209)\end{array}$ & $\begin{array}{l}0.000953 \\
(0.0239)\end{array}$ & $\begin{array}{l}-0.00946 \\
(0.0238)\end{array}$ \\
\hline Partnership & $\begin{array}{l}-0.0309 \\
(0.0439)\end{array}$ & $\begin{array}{l}0.0143 \\
(0.0482)\end{array}$ & $\begin{array}{l}-0.0364 \\
(0.0479)\end{array}$ \\
\hline Limited liability corporation & $\begin{array}{l}-0.0125 \\
(0.0225)\end{array}$ & $\begin{array}{l}-0.0152 \\
(0.0262)\end{array}$ & $\begin{array}{l}0.0358 \\
(0.0253)\end{array}$ \\
\hline Corporation & $\begin{array}{l}-0.0146 \\
(0.0243)\end{array}$ & $\begin{array}{l}-0.0521 * \\
(0.0272)\end{array}$ & $\begin{array}{l}0.0634 * * \\
(0.0267)\end{array}$ \\
\hline Home based & $\begin{array}{l}-0.0271 \\
(0.0180)\end{array}$ & $\begin{array}{l}-0.0101 \\
(0.0206)\end{array}$ & $\begin{array}{l}-0.0528^{* * *} \\
(0.0203)\end{array}$ \\
\hline Comparative advantage & $\begin{array}{l}-0.00942 \\
(0.0172)\end{array}$ & $\begin{array}{l}-0.0504^{* *} \\
(0.0199)\end{array}$ & $\begin{array}{l}0.0220 \\
(0.0198)\end{array}$ \\
\hline Intellectual property & $\begin{array}{l}0.0692 * * * \\
(0.0196)\end{array}$ & $\begin{array}{l}0.105 * * * \\
(0.0235)\end{array}$ & $\begin{array}{l}0.0448^{*} \\
(0.0234)\end{array}$ \\
\hline Observations & 4,036 & 4,036 & 4,036 \\
\hline
\end{tabular}

FK, financial capital

$* * * p<0.01, * * p<0.05$, $* p<0.1$

Robust standard errors are given in parenthesis; 2-digit industry dummies are included 
total broken out into equity and debt. Independent variables include characteristics of the firm and owner characteristics that prior research has indicated may affect access to capital or capital structure.

The results provided in Table 4 indicate that highly educated owners, that is firm owners who attended college, graduated from college, and obtained a graduate degree, were significantly more likely to have new financial investments in the follow-on years of 2005-2006. Similarly, owners who had prior start-up experience and those who worked more hours in an average week were significantly more likely to secure additional financing. Finally, firms that had some type of intellectual property (patents, trademarks, and/or copyrights) were more likely to obtain new financing. Industry is also controlled for in all of the multivariate regressions at the two digit North American Classification System (NAICS) level, but not presented. Respondents were asked if they thought their firm had a comparative advantage in the product(s) or service(s) it offered. The results for comparative advantage were mixed in the multivariate analyses, sometimes positive and sometimes negative, and rarely statistically significant. Even after controlling for various firm and owner characteristics, womenowned firms were significantly less likely to have new financial investments. This distinction held for new injections, as well as new equity and new debt investments. In each instance, women-owned firms were significantly less likely to have new investments than firms owned by men.

It is noteworthy that some of the variables associated with new investment are precisely those characteristics that one does not typically associate with women-owned firms. In particular, owners who worked more hours were significantly more likely to obtain new financial investment, new equity, and new debt. Women may be less likely to work long hours due to the need to balance work/home responsibilities (Boden 1999). Similarly, firms that have some type of intellectual property were significantly more likely to obtain new financial investment, new equity, and new debt. Prior research reveals that women tend to start firms in service and retail and are much less likely to start firms in engineering or technology fields where there would be barriers to entry in the form of intellectual property (Menzies et al. 2004; Morris et al. 2006).

\subsection{Amounts of financing}

Tables 5, 6, and 7 use linear regression to examine the amount of initial and follow-on financing for women- and men-owned firms. Dependent variables include (1) the log of total financial investment, (2) the $\log$ of total equity investment, and (3) the log of total debt investment. Table 5 reveals that firm owners who were older and those who devoted more hours to their business had significantly higher amounts of start-up capital in 2004. This was true for both equity investment and debt investment as well. Similarly, firms that were owned by a team, those that had limited liability, and those that were organized as corporations had significantly higher amounts of total, equity, and debt investment. Conversely, home-based businesses had significantly smaller amounts of investment, possibly because their capital requirements are minimal. Firm owners who were better educated had significantly higher amounts of total investment and equity. Surprisingly, those owners who had fewer years of work experience also had higher amounts of investment. Twodigit NAICS codes are also controlled for in all of these regressions. Finally, Table 5 reveals that, consistent with our findings in Table 3, women started their firms with significantly lower amounts of total financial investment, equity investment, and debt investment than men, even after controlling for many other factors that should affect levels of start up capital.

Table 6 uses the same dependent and independent variables to explore differences in the amount of follow-on financing for the combined years of 2005 and 2006. Firm owners who used significantly larger amounts of follow-on financing in the form of both debt and equity devoted more hours in an average week to the business and had prior start-up experience. Firms that had limited liability protection, those organized as corporations, and those that had some type of intellectual property (patents, copyrights, and/or trademarks) also used significantly larger amounts of total new investment, new equity, and new debt. In general, higher levels of education, fewer years of work experience, and team ownership were also associated with larger amounts of new investment. Conversely, home-based firms continued to use significantly lower levels of financial investment. As seen in Table 5, women-owned firms used significantly smaller 
Table 5 Linear models for log of total start-up capital, equity, and debt start-up capital (2004)

\begin{tabular}{|c|c|c|c|c|}
\hline \multirow{2}{*}{$\begin{array}{l}\text { Table } 5 \text { Linear models for } \\
\text { log of total start-up capital, } \\
\text { equity, and debt start-up } \\
\text { capital (2004) }\end{array}$} & Coefficients & $\begin{array}{l}\text { Log of } 2004 \text { financial } \\
\text { investments }\end{array}$ & $\begin{array}{l}\text { Log of } 2004 \text { equity } \\
\text { investments }\end{array}$ & $\begin{array}{l}\text { Log of } 2004 \text { debt } \\
\text { investments }\end{array}$ \\
\hline & Black & $-0.614 * * *$ & $-0.285^{* *}$ & $-0.829 * * *$ \\
\hline & & $(0.116)$ & $(0.116)$ & $(0.122)$ \\
\hline & Asian & $0.553 * * *$ & $0.387 * *$ & $0.416^{*}$ \\
\hline & & $(0.157)$ & $(0.177)$ & $(0.244)$ \\
\hline & Other & -0.0423 & -0.130 & 0.112 \\
\hline & & $(0.232)$ & $(0.256)$ & $(0.273)$ \\
\hline & Hispanic & -0.0181 & 0.0366 & -0.0854 \\
\hline & & $(0.152)$ & $(0.157)$ & $(0.189)$ \\
\hline & Female & $-0.236 * * *$ & $-0.290 * * *$ & -0.102 \\
\hline & & $(0.0849)$ & $(0.0846)$ & $(0.0999)$ \\
\hline & Hours worked & $0.0209 * * *$ & $0.0171 * * *$ & $0.0159 * * *$ \\
\hline & & $(0.00169)$ & $(0.00166)$ & $(0.00194)$ \\
\hline & Age & $0.0667 * * *$ & $0.0497 * *$ & $0.0630 * * *$ \\
\hline & & $(0.0221)$ & $(0.0220)$ & $(0.0243)$ \\
\hline & Age squared & $-0.000566^{* *}$ & -0.000333 & $-0.000622 * *$ \\
\hline & & $(0.000236)$ & $(0.000235)$ & $(0.000256)$ \\
\hline & High school graduate & $0.629 * *$ & 0.481 & -0.112 \\
\hline & & $(0.296)$ & $(0.301)$ & $(0.336)$ \\
\hline & Some college & $0.748 * * *$ & $0.611 * *$ & 0.0364 \\
\hline & & $(0.279)$ & $(0.286)$ & $(0.318)$ \\
\hline & College degree & $0.815 * * *$ & $0.809 * * *$ & -0.00550 \\
\hline & & $(0.283)$ & $(0.289)$ & $(0.323)$ \\
\hline & Graduate degree & $0.864 * * *$ & $0.831 * * *$ & 0.0159 \\
\hline & & $(0.289)$ & $(0.295)$ & $(0.331)$ \\
\hline & Work experience (years) & $-0.0154 * * *$ & $-0.00877 * *$ & $-0.0142 * * *$ \\
\hline & & $(0.00394)$ & $(0.00397)$ & $(0.00470)$ \\
\hline & Start-up experience & 0.104 & $0.199 * * *$ & 0.0000450 \\
\hline & & $(0.0762)$ & $(0.0773)$ & $(0.0885)$ \\
\hline & Team ownership & $0.434 * * *$ & $0.390 * * *$ & $0.268^{* *}$ \\
\hline & & $(0.0967)$ & $(0.0987)$ & $(0.119)$ \\
\hline & Partnership & -0.00814 & 0.270 & $-0.406^{*}$ \\
\hline & & $(0.194)$ & $(0.199)$ & $(0.227)$ \\
\hline & Limited liability corporation & $0.513 * * *$ & $0.618 * * *$ & $0.334 * * *$ \\
\hline & & $(0.0996)$ & $(0.100)$ & $(0.116)$ \\
\hline & Corporation & $0.506 * * *$ & $0.558 * * *$ & $0.414 * * *$ \\
\hline & & $(0.103)$ & $(0.106)$ & $(0.125)$ \\
\hline & Home based & $-0.657 * * *$ & $-0.541 * * *$ & $-0.607 * * *$ \\
\hline & & $(0.0826)$ & $(0.0816)$ & $(0.0958)$ \\
\hline & Comparative advantage & 0.104 & 0.116 & 0.115 \\
\hline & & $(0.0773)$ & $(0.0776)$ & $(0.0905)$ \\
\hline & Intellectual property & 0.119 & 0.141 & 0.00657 \\
\hline & & $(0.0910)$ & $(0.0950)$ & $(0.112)$ \\
\hline$* p<0.1$ & Constant & $6.477 * * *$ & $6.137 * * *$ & $6.773 * * *$ \\
\hline Robust standard errors are & & $(0.892)$ & $(0.690)$ & $(0.763)$ \\
\hline given in parenthesis; 2 -digit & Observations & 3,289 & 3,292 & 3,292 \\
\hline $\begin{array}{l}\text { industry dummies are } \\
\text { included }\end{array}$ & $R^{2}$ & 0.249 & 0.212 & 0.153 \\
\hline
\end{tabular}


Table 6 New financial injections $(2005+2006)$ (active firms)
$* * * p<0.01, * * p<0.05$,

$* p<0.1$

Robust standard errors are given in parenthesis; 2-digit industry dummies are included

\begin{tabular}{|c|c|c|c|}
\hline Coefficients & $\begin{array}{l}\text { Log of new financial } \\
\text { investments }\end{array}$ & $\begin{array}{l}\text { Log of new equity } \\
\text { investments }\end{array}$ & $\begin{array}{l}\text { Log of new debt } \\
\text { investments }\end{array}$ \\
\hline Black & $\begin{array}{l}-0.146 \\
(0.152)\end{array}$ & $\begin{array}{l}0.422 * * * \\
(0.135)\end{array}$ & $\begin{array}{l}-0.395 * * \\
(0.161)\end{array}$ \\
\hline Asian & $\begin{array}{l}0.208 \\
(0.212)\end{array}$ & $\begin{array}{l}0.111 \\
(0.217)\end{array}$ & $\begin{array}{l}0.164 \\
(0.238)\end{array}$ \\
\hline Other & $\begin{array}{l}-0.125 \\
(0.293)\end{array}$ & $\begin{array}{l}0.212 \\
(0.282)\end{array}$ & $\begin{array}{l}-0.223 \\
(0.313)\end{array}$ \\
\hline Hispanic & $\begin{array}{l}0.179 \\
(0.175)\end{array}$ & $\begin{array}{l}0.261 \\
(0.173)\end{array}$ & $\begin{array}{l}0.180 \\
(0.195)\end{array}$ \\
\hline Female & $\begin{array}{l}-0.649 * * * \\
(0.101)\end{array}$ & $\begin{array}{l}-0.290^{* * * *} \\
(0.0925)\end{array}$ & $\begin{array}{l}-0.568^{* * *} \\
(0.107)\end{array}$ \\
\hline Hours worked & $\begin{array}{l}0.0182 * * * \\
(0.00198)\end{array}$ & $\begin{array}{l}0.0130 * * * \\
(0.00186)\end{array}$ & $\begin{array}{l}0.0163 * * * \\
\backslash(0.00213)\end{array}$ \\
\hline Age & $\begin{array}{l}0.0424 * \\
(0.0253)\end{array}$ & $\begin{array}{l}-0.0160 \\
(0.0237)\end{array}$ & $\begin{array}{l}0.0426 \\
(0.0269)\end{array}$ \\
\hline Age squared & $\begin{array}{l}-0.000392 \\
(0.000269)\end{array}$ & $\begin{array}{l}0.000292 \\
(0.000253)\end{array}$ & $\begin{array}{l}-0.000451 \\
(0.000284)\end{array}$ \\
\hline High school graduate & $\begin{array}{l}0.623 * \\
(0.329)\end{array}$ & $\begin{array}{l}0.129 \\
(0.303)\end{array}$ & $\begin{array}{l}0.457 \\
(0.349)\end{array}$ \\
\hline Some college & $\begin{array}{l}0.591 * \\
(0.308)\end{array}$ & $\begin{array}{l}0.0810 \\
(0.286)\end{array}$ & $\begin{array}{l}0.518 \\
(0.327)\end{array}$ \\
\hline College degree & $\begin{array}{l}0.608 * \\
(0.313)\end{array}$ & $\begin{array}{l}0.160 \\
(0.290)\end{array}$ & $\begin{array}{l}0.505 \\
(0.332)\end{array}$ \\
\hline Graduate degree & $\begin{array}{l}0.702 * * \\
(0.322)\end{array}$ & $\begin{array}{l}0.446 \\
(0.300)\end{array}$ & $\begin{array}{l}0.502 \\
(0.341)\end{array}$ \\
\hline Work experience (years) & $\begin{array}{l}-0.0125^{* * *} \\
(0.00450)\end{array}$ & $\begin{array}{l}-0.00385 \\
(0.00441)\end{array}$ & $\begin{array}{l}-0.0151 * * * \\
(0.00495)\end{array}$ \\
\hline Start up experience & $\begin{array}{l}0.324 * * * \\
(0.0877)\end{array}$ & $\begin{array}{l}0.367 * * * \\
(0.0855)\end{array}$ & $\begin{array}{l}0.230 * * \\
(0.0957)\end{array}$ \\
\hline Team ownership & $\begin{array}{l}0.356^{* * * *} \\
(0.113)\end{array}$ & $\begin{array}{l}0.284 * * \\
(0.114)\end{array}$ & $\begin{array}{l}0.166 \\
(0.123)\end{array}$ \\
\hline Partnership & $\begin{array}{l}0.0919 \\
(0.225)\end{array}$ & $\begin{array}{l}0.171 \\
(0.222)\end{array}$ & $\begin{array}{l}-0.105 \\
(0.238)\end{array}$ \\
\hline Limited liability corporation & $\begin{array}{l}0.449 * * * \\
(0.115)\end{array}$ & $\begin{array}{l}0.285^{* * *} \\
(0.109)\end{array}$ & $\begin{array}{l}0.455^{* * * *} \\
(0.126)\end{array}$ \\
\hline Corporation & $\begin{array}{l}0.663 * * * \\
(0.128)\end{array}$ & $\begin{array}{l}0.234^{*} \\
(0.121)\end{array}$ & $\begin{array}{l}0.802 * * * \\
(0.138)\end{array}$ \\
\hline Home based & $\begin{array}{l}-0.473 * * * \\
(0.0944)\end{array}$ & $\begin{array}{l}-0.271 * * * \\
(0.0909)\end{array}$ & $\begin{array}{l}-0.513 * * * \\
(0.102)\end{array}$ \\
\hline Comparative advantage & $\begin{array}{l}-0.0826 \\
(0.0896)\end{array}$ & $\begin{array}{l}-0.164 * \\
(0.0844)\end{array}$ & $\begin{array}{l}0.0271 \\
(0.0972)\end{array}$ \\
\hline Intellectual property & $\begin{array}{l}0.351 * * * \\
(0.107)\end{array}$ & $\begin{array}{l}0.483 * * * \\
(0.111)\end{array}$ & $\begin{array}{l}0.0779 \\
(0.119)\end{array}$ \\
\hline Constant & $\begin{array}{l}7.634 * * * \\
(0.755)\end{array}$ & $\begin{array}{l}8.168 * * * \\
(0.722)\end{array}$ & $\begin{array}{l}7.277 * * * \\
(0.811)\end{array}$ \\
\hline Observations & 3,292 & 3,292 & 3,292 \\
\hline$R^{2}$ & 0.187 & 0.104 & 0.154 \\
\hline
\end{tabular}


Table 7 Multivariate analyses for active firms (controls for start-up capital and sales) new financial injections $(2005+2006)$

\begin{tabular}{|c|c|c|c|}
\hline Coefficients & $\begin{array}{l}\text { Log of new financial } \\
\text { investments }\end{array}$ & $\begin{array}{l}\text { Log of new equity } \\
\text { investments }\end{array}$ & $\begin{array}{l}\text { Log of new debt } \\
\text { investments }\end{array}$ \\
\hline Black & $\begin{array}{l}0.238^{*} \\
(0.137)\end{array}$ & $\begin{array}{l}0.593 * * * \\
(0.131)\end{array}$ & $\begin{array}{l}0.0288 \\
(0.147)\end{array}$ \\
\hline Asian & $\begin{array}{l}0.000575 \\
(0.203)\end{array}$ & $\begin{array}{l}-0.0551 \\
(0.226)\end{array}$ & $\begin{array}{l}-0.0210 \\
(0.212)\end{array}$ \\
\hline Other & $\begin{array}{l}-0.0324 \\
(0.260)\end{array}$ & $\begin{array}{l}0.219 \\
(0.241)\end{array}$ & $\begin{array}{l}-0.100 \\
(0.286)\end{array}$ \\
\hline Hispanic & $\begin{array}{l}0.265^{*} \\
(0.157)\end{array}$ & $\begin{array}{l}0.260 \\
(0.164)\end{array}$ & $\begin{array}{l}0.299 * \\
(0.181)\end{array}$ \\
\hline Female & $\begin{array}{l}-0.514 * * * \\
(0.0937)\end{array}$ & $\begin{array}{l}-0.224 * * \\
(0.0896)\end{array}$ & $\begin{array}{l}-0.423 * * * \\
(0.101)\end{array}$ \\
\hline Hours worked & $\begin{array}{l}0.00749 * * * \\
(0.00202)\end{array}$ & $\begin{array}{l}0.00709 * * * \\
(0.00197)\end{array}$ & $\begin{array}{l}0.00509 * * \\
(0.00218)\end{array}$ \\
\hline Age & $\begin{array}{l}0.0117 \\
(0.0230)\end{array}$ & $\begin{array}{l}-0.0343 \\
(0.0231)\end{array}$ & $\begin{array}{l}0.0114 \\
(0.0246)\end{array}$ \\
\hline Age squared & $\begin{array}{l}-0.000116 \\
(0.000244)\end{array}$ & $\begin{array}{l}0.000444^{*} \\
(0.000246)\end{array}$ & $\begin{array}{l}-0.000162 \\
(0.000261)\end{array}$ \\
\hline High school graduate & $\begin{array}{l}0.279 \\
(0.351)\end{array}$ & $\begin{array}{l}-0.0492 \\
(0.290)\end{array}$ & $\begin{array}{l}0.0926 \\
(0.379)\end{array}$ \\
\hline Some college & $\begin{array}{l}0.216 \\
(0.334)\end{array}$ & $\begin{array}{l}-0.133 \\
(0.273)\end{array}$ & $\begin{array}{l}0.132 \\
(0.360)\end{array}$ \\
\hline College degree & $\begin{array}{l}0.153 \\
(0.337)\end{array}$ & $\begin{array}{l}-0.0651 \\
(0.277)\end{array}$ & $\begin{array}{l}0.0157 \\
(0.364)\end{array}$ \\
\hline Graduate degree & $\begin{array}{l}0.233 \\
(0.344)\end{array}$ & $\begin{array}{l}0.202 \\
(0.286)\end{array}$ & $\begin{array}{l}0.00471 \\
(0.372)\end{array}$ \\
\hline Work experience (years) & $\begin{array}{l}-0.00772 * \\
(0.00422)\end{array}$ & $\begin{array}{l}0.00105 \\
(0.00432)\end{array}$ & $\begin{array}{l}-0.0116^{* *} \\
(0.00470)\end{array}$ \\
\hline Start-up experience & $\begin{array}{l}0.271 * * * \\
(0.0816)\end{array}$ & $\begin{array}{l}0.339 * * * \\
(0.0826)\end{array}$ & $\begin{array}{l}0.173^{*} \\
(0.0901)\end{array}$ \\
\hline Team ownership & $\begin{array}{l}0.161 \\
(0.107)\end{array}$ & $\begin{array}{l}0.161 \\
(0.112)\end{array}$ & $\begin{array}{l}-0.0268 \\
(0.117)\end{array}$ \\
\hline Partnership & $\begin{array}{l}0.0748 \\
(0.205)\end{array}$ & $\begin{array}{l}0.200 \\
(0.216)\end{array}$ & $\begin{array}{l}-0.155 \\
(0.218)\end{array}$ \\
\hline Limited liability corporation & $\begin{array}{l}0.145 \\
(0.107)\end{array}$ & $\begin{array}{l}0.136 \\
(0.107)\end{array}$ & $\begin{array}{l}0.129 \\
(0.119)\end{array}$ \\
\hline Corporation & $\begin{array}{l}0.321 * * * \\
(0.121)\end{array}$ & $\begin{array}{l}0.0906 \\
(0.119)\end{array}$ & $\begin{array}{l}0.422^{* * *} \\
(0.130)\end{array}$ \\
\hline Home based & $\begin{array}{l}-0.0814 \\
(0.0905)\end{array}$ & $\begin{array}{l}-0.0869 \\
(0.0900)\end{array}$ & $\begin{array}{l}-0.0865 \\
(0.0992)\end{array}$ \\
\hline Comparative advantage & $\begin{array}{l}-0.167 * * \\
(0.0848)\end{array}$ & $\begin{array}{l}-0.191 * * \\
(0.0825)\end{array}$ & $\begin{array}{l}-0.0730 \\
(0.0933)\end{array}$ \\
\hline Intellectual property & $\begin{array}{l}0.328 * * * \\
(0.0991)\end{array}$ & $\begin{array}{l}0.442 * * * \\
(0.107)\end{array}$ & $\begin{array}{l}0.0712 \\
(0.111)\end{array}$ \\
\hline Log of start up capital (2004) & $\begin{array}{l}0.400^{* * *} \\
(0.0249)\end{array}$ & $\begin{array}{l}0.295 * * * \\
(0.0239)\end{array}$ & $\begin{array}{l}0.370 * * * \\
(0.0270)\end{array}$ \\
\hline
\end{tabular}


Table 7 continued

$* * * p<0.01, * * p<0.05$

$* p<0.1$

Robust standard errors are given in parenthesis; 2-digit industry dummies are included

\begin{tabular}{llll}
\hline Coefficients & $\begin{array}{l}\text { Log of new financial } \\
\text { investments }\end{array}$ & $\begin{array}{l}\text { Log of new equity } \\
\text { investments }\end{array}$ & $\begin{array}{l}\text { Log of new debt } \\
\text { investments }\end{array}$ \\
\hline $\begin{array}{l}\text { Log of average sales } \\
\quad(2005 \text { and 2006) }\end{array}$ & $\begin{array}{l}0.187 * * * \\
(0.0328)\end{array}$ & -0.0138 & $0.264 * * *$ \\
Constant & $3.390^{* * *}$ & $(0.0336)$ & $(0.0364)$ \\
& $(0.773)$ & $6.317 * * *$ & $2.585 * * *$ \\
Observations & 3,289 & $(0.764)$ & $(0.837)$ \\
$R^{2}$ & 0.299 & 3,289 & 3,289 \\
\hline
\end{tabular}

amounts of total new investment, new equity, and new debt.

As a final step, we repeat the exercise with the model used to generate Table 6 , but add the $\log$ of start-up capital (2004) and the log of 2005-2006 average sales as independent variables. The results shown in Table 7 reveal that, even controlling for the amount of start-up capital and the sales level, womenowned firms still used lower amounts of new financial investments, new equity, and new debt.

\section{Summary and conclusions}

In this paper we present a preliminary examination of differences in new firm financing by gender using data from the Kauffman Firm Survey, a longitudinal survey of nearly 5,000 new firms in the USA. Our results reveal that, consistent with prior research, women started their firms with significantly less capital than men. A new finding from our research is that women also went on to raise significantly smaller amounts of follow-on capital, both debt and equity. Our findings show that women relied more heavily on personal rather than external sources of financing. In fact, by the third year of operation, approximately twice as many men were using external debt, such as bank loans for the business or lines of credit, as women, although a low percentage of both women and men used external equity.

Prior research has suggested both supply side and demand side constraints on women's access to capital. In terms of supply side constraints, investors may choose to avoid newer firms in general because they lack a track record and have a greater risk of failure. Supply side constraints could also include investors' preferences for certain types of businesses or subtle forms of discrimination that exclude women from networks that could provide them access to capital. These results reveal that higher levels of investment were associated with characteristics such as devoting more hours to the business, prior start-up experience, being organized as a corporation, and having intellectual property protection, none of which are typical of women business owners.

The fact that women in this study raised significantly less capital, even controlling for the level of start-up capital and sales, and relied heavily on personal sources of debt and equity may also be evidence of demand side constraints. Prior research attests to a higher level of risk aversion on the part of women, a desire for smaller firms that allow for work/ family balance, and a desire to maintain control. These motivations may cause women to start smaller firms requiring smaller amounts of capital that can be supplied by personal rather than external sources. Whatever the cause, the fact that women use dramatically smaller amounts of start-up capital and rely on personal rather than external sources has implications for their ability to develop new products and services, grow their firms, hire employees, and survive periods of adversity.

This study lays the groundwork for further research on gender differences in financing sources and strategies. First, these findings suggest the possibility of both supply and demand side constraints on women's access to capital. Further study is needed to delve into these issues to determine precisely why women use the financing sources they do and why they avoid or are discouraged from others. Further research could also shed light on whether women raise smaller amounts of capital because they do not feel they need it, or alternatively, because they are unable to get it. A second possible direction for further research would be an examination of the link between financing sources and strategy and firm outcomes in 
the form of sales, profits, growth, and employment. Specifically, are women at a disadvantage in terms of performance outcomes because of the financing sources and strategies they use? It is our intent to use these preliminary results to continue our investigation into these questions. As additional years of data are added to the Kauffman Firm Survey, this database will continue to be an invaluable resource to examine these issues.

Open Access This article is distributed under the terms of the Creative Commons Attribution Noncommercial License which permits any noncommercial use, distribution, and reproduction in any medium, provided the original author(s) and source are credited.

\section{References}

Alsos, G. A., Espen, J. I., \& Ljunggren, E. (2006). New venture financing and subsequent business growth in men- and women-led businesses. Entrepreneurship Theory and Practice, 30(5), 667-686.

Amatucci, F. M., \& Sohl, J. E. (2004). Women entrepreneurs securing business angel financing: Tales from the field. Venture Capital, 6(2/3), 181-196.

Anna, A. L., Chandler, G. N., Jansen, E., \& Mero, N. P. (1999). Women business owners in traditional and non-traditional industries. Journal of Business Venturing, 15(3), 279-303.

Ballou, J., Barton, T., DesRoches, D., Potter, F., Reedy, E. J., Robb, A., et al. (2008). Kauffman firm survey: Results from the baseline and first follow-up surveys. Kansas City, MO: Kauffman Foundation.

Becker-Blease, J. R., \& Sohl, J. E. (2007). Do women-owned businesses have equal access to angel capital? Journal of Business Venturing, 22(4), 503-521.

Boden, R. J., Jr. (1999). Flexible working hours, family responsibilities, and female self-employment: gender differences in self-employment selection. The American Journal of Economics and Sociology, 58(1), 71-83.

Boden, R. J., \& Nucci, A. R. (2000). On the survival prospects of men's and women's new business ventures. Journal of Business Venturing, 15(4), 347-362.

Brush, C. G. (1992). Research on women business owners: past trends, a new perspective, and future directions. Entrepreneurship Theory and Practice, 16(4), 5-30.

Brush, C., Carter, N., Gatewood, E., Greene, P., \& Hart, M. (2001). The Diana project: Women business owners and equity capital: The myths dispelled. Kansas City, MO: Kauffman Center for Entrepreneurial Leadership.

Brush, C. G., Carter, N. M., Greene, P. G., Hart, M. M., \& Gatewood, E. (2002). The role of social capital and gender in linking financial suppliers and entrepreneurial firms: A framework for future research. Venture Capital, 4(4), 305-323.

Carter, N. M., Williams, M., \& Reynolds, P. D. (1997). Discontinuance among new firms in retail: The influence of initial resources, strategy, and gender. Journal of Business Venturing, 12(2), 125-145.

Carter, N. M., Brush, C. G., Greene, P. G., Gatewood, E., \& Hart, M. M. (2003a). Women entrepreneurs who break through to equity financing: The influence of human, social, and financial capital. Venture Capital, 5(1), 1-28.

Carter, N. M., Gartner, W. B., Shaver, K. G., \& Gatewood, E. J. (2003b). The career reasons of nascent entrepreneurs. Journal of Business Venturing, 18(1), 13-39.

Chaganti, R., DeCarolis, D., \& Deeds, D. (1996). Predictors of capital structure in small ventures. Entrepreneurship Theory and Practice, 20(2), 7-18.

Cliff, J. E. (1998). Does one size fit all? Exploring the relationship between attitudes toward growth, gender, and business size. Journal of Business Venturing, 13, 523542.

Cole, R. A., \& Mehran, H. (2009). Gender and the availability of credit to privately held firms. Paper first presented at the Kauffman-Federal Reserve Conference on Entrepreneurial Finance, Cleveland Ohio, March 11-12, 2008. http://ssrn.com/abstract-1354781.

Coleman, S. (2002). Characteristics and borrowing behavior of small, women-owned firms: Evidence from the 1998 survey of small business finances. Journal of Business and Entrepreneurship, 14(2), 151-166.

Constantinidis, C., Cornet, A., \& Asandei, S. (2006). Financing of women-owned ventures: The impact of gender and other owner- and firm-related variables. Venture Capital, $8(2), 133-157$.

Du Rietz, A., \& Henrekson, M. (2000). Testing the female underperformance hypothesis. Small Business Economics, 14(1), 1-10.

Fabowale, L., Orser, B., \& Riding, A. (1995). Gender, structural factors, and credit terms between Canadian small businesses and financial institutions. Entrepreneurship Theory and Practice, 19(4), 41-65.

Fairlie, R. W., \& Robb, A. M. (2008). Race and entrepreneurial success: Black-, Asian-, and White-owned businesses in the United States. Cambridge, MA: MIT Press.

Fairlie, R. W., \& Robb, A. M. (2009). Gender differences in business performance: evidence from the characteristics of business owners survey. Small Business Economics. doi:10.1007/s11187-009-9207-5.

Frequently asked questions (2008). Available at: http://www. sba.gov/faqs. Retrieved 12 Feb 2008.

Haynes, G. W., Rowe, B. R., Walker, R., \& Hong, G. (2000). The differences in financial structure between womenand men-owned family businesses. Journal of Family and Economic Issues, 21(3), 209-226.

Kalleberg, A. L., \& Leicht, K. T. (1991). Gender and organizational performance: Determinants of small business survival and success. Academy of Management Journal, 34(1), 136-161.

Key facts about women-owned businesses. Available at: http://www.womensbusinessresearch.org/facts. Retrieved 12 Feb 2008.

Lee, S., \& Denslow, D. (2004). A study on the major problems of U.S. women-owned small businesses. Journal of Small Business Strategy, 15(2), 77-89.

Loscocco, K. A., Robinson, J., Hall, R. H., \& Allen, J. K. (1991). Gender and small business success: An inquiry 
into women's relative disadvantage. Social Forces, 70(1), 65-85.

Marlow, S., \& Patton, D. (2005). All credit to men? Entrepreneurship, finance, and gender. Entrepreneurship Theory and Practice, 29(3), 526-541.

Menzies, T. V., Diochon, M., \& Gasse, Y. (2004). Examining venture-related myths concerning women entrepreneurs. Journal of Developmental Entrepreneurship, 9(2), 89-107.

Morris, M. H., Miyasaki, N. N., Watters, C. E., \& Coombes, S. M. (2006). The dilemma of growth: Understanding venture size choices of women entrepreneurs. Journal of Small Business Management, 44(2), 221-244.

Orser, B., \& Hogarth-Scott, S. (2002). Opting for growth: Gender dimensions of choosing enterprise development. Canadian Journal of Administrative Sciences, 19(3), 284-300.

Orser, B., Hogarth-Scott, S., \& Riding, A. (2000). Performance, firm size, and management problem solving. Journal of Small Business Management, 38(4), 42-48.

Orser, B. J., Riding, A. L., \& Manley, K. (2006). Women entrepreneurs and financial capital. Entrepreneurship Theory and Practice, 30(5), 643-665.

Parker, S. C., \& Belghitar, Y. (2006). What happens to nascent entrepreneurs? An econometric analysis of the PSED. Small Business Economics, 27, 81-101.

Robb, A. M. (2002). Entrepreneurial performance by women and minorities: The case of new firms. Journal of Developmental Entrepreneurship, 7(4), 383-397.

Robb, A. M., \& Wolken, J. (2002). Firm, owner, and financing characteristics: Differences between female- and male- owned small businesses. Federal Reserve Working Paper Series: 2002-18. Federal Reserve Board of Governors: Washington D.C.

Rosa, P., Carter, S., \& Hamilton, D. (1996). Gender as a determinant of small business performance: Insights from a British study. Small Business Economics, 8(6), 463-478.

Survey of Business Owners. (2002). Available at: http://www. census.gov/csd/sbo/. Retrieved 26 June 2008.

Treichel, M. Z., \& Scott, J. A. (2006). Women-owned businesses and access to bank credit: Evidence from three surveys since 1987. Venture Capital, 8(1), 51-67.

U.S. Census Bureau (2001). 1997 Survey of Women-Owned Enterprises Company Statistics Series. Washington, D.C.: USGPO.

U.S. Census Bureau (2006). 2002 Economic Census, Survey of Business Owners Company Statistics Series. Washington, D.C.: USGPO.

Verheul, I., \& Thurik, R. (2001). Start-up capital: "Does gender matter?". Small Business Economics, 16(4), 329-345.

Walker, D., \& Joyner, B. E. (1999). Female entrepreneurship and the market process: Gender-based public policy considerations. Journal of Developmental Entrepreneurship, 4(2), 95-116.

Watson, J. (2002). Comparing the performance of male- and female-controlled businesses: Relating outputs to inputs. Entrepreneurship Theory and Practice, 26(3), 91-100. 